\title{
Estranhamento e riso no cinema contemporâneo
}

PABlo Augusto Silva e Rogério FERreira ANTUNES

\section{Sinopse: A hora do show}

$P$ IERRE Delacroix é o roteirista de uma rede de TV que passa por sérios problemas: concorrência, TV a cabo, jogos eletrônicos, videogame e internet são os motivos da queda de audiência. Pressionado por seu chefe, Thomas Dunwitty (Michael Rapaport), a criar um programa de sucesso, o roteirista recria os antigos shows de menestréis. Esses shows, surgidos por volta de 1840 nos Estados Unidos, eram um misto de dança, teatro, circo, piada, malabarismo e sapateado em que atores, brancos e negros, pintavam o rosto de preto e a boca de batom vermelho, fazendo uma caricatura do negro e de seu modo de vida. Delacroix contrata dois artistas de rua, um ator - Come-e-Dorme (Tommy Davidson) - e um bailarino de sapateado - Man Ray (Savion Glover) -, para serem os protagonistas. Inicialmente, o roteirista não tem esperanças de que o programa seja aceito em razão mesmo da natureza preconceituosa do programa. No entanto, para surpresa de Delacroix, o programa é aceito com entusiasmo pelos donos da rede de TV. Os primeiros programas-piloto são rodados e apresentados a uma plateia que serve de amostra do público que assiste à TV. As primeiras sensações de incômodo são substituídas pelo riso que emerge das figuras engraçadas: negros pintados de negros. Mantan - o menestrel do novo milênio, programa assim intitulado, é um sucesso estrondoso de público e de crítica. Pierre Delacroix fica famoso. A emissora atrai anunciantes que pagam fortunas com o intuito de vender seus produtos à "população afro-americana": bebida alcoólica, roupas esportivas, produtos eróticos, música de baixa qualidade. Entretanto, o filme não agrada a uma parcela da comunidade afro-americana que se sente desrespeitada pela emissora, ao tratar os negros como brinquedo de diversão para a sociedade americana. Protestos de líderes religiosos, intelectuais, militantes, artistas e jovens rappers radicais geram um amplo debate sobre o racismo que perpassa a sociedade contemporânea permeada pelo consumo da imagem. A morte de um dos atores por parte de "radicais" é consequência de toda essa complexa rede de relações que entrelaça história e imaginário.

\section{A imagem eurocêntrica e o fardo da representação}

Quem assistir ao filme A hora do show (2000), dirigido por Spike Lee, sentirá algo a que não estamos acostumados quando nos debruçamos sobre a telona: não choramos, mas também não rimos, não nos entretemos e muito menos 
conseguimos ter uma fruição estética. Um diretor de cinema que divide opiniões as mais diversas, e ele tem plena consciência disso, faz uso da imagem para além de sua mera exposição, qual seja, da imagem deixada ao espectador as leituras possíveis que podem ser feitas de cada cena ou fotografia. Em $A$ hora do show, Spike Lee tem um propósito. Em vez de abordar o racismo e o preconceito de maneira direta, como gostam de dizer seus críticos, ele aborda pelo humor, mas não o humor carnavalesco que humoriza, por meio de piadas, anedotas e tipos, sua própria condição. Spike Lee aponta para uma dimensão do humor como um recurso para a crítica dos valores intrínsecos a uma determinada cosmovisão (weltanschaunng). Colocando o humor de maneira nua, isto é, mostrando o que a sociedade almeja com um programa desses - divertir-se à custa da indiferença à alteridade -, o diretor tem uma percepção mais radical do mundo em que vive e em que vivemos.

A obra de Spike Lee é aberta no sentido moderno do termo, quer dizer, ela exige um telespectador ativo, que questiona, que fala, que tem raiva, que xinga a obra, que a elogia, enfim, que não tenha uma atitude passiva. $A$ hora do show não só desnuda o racismo que atravessa a indústria cultural, como também faz verdadeira etnografia do modo de vida do negro americano habitante das grandes cidades atravessado pela repulsa e pelo fascínio da sociedade de consumo. Fascínio porque, no filme, o negro americano também é americano e partilha de seu modo de vida (american way of life); e repulsa porque, cercado pelo racismo de um meio urbano violento, aqueles que não se enquadrarem em padrões (estéticos, hábitos e estilos) tornam-se alvos ou possíveis bodes expiratórios. Spike Lee mostra como as identidades contemporâneas passam pelo consumo não apenas de produtos, mas de imagem de produtos que a ultrapassam, tornando-se fetiche. A ideia da TV como uma caixa de imagens não é aleatória, pois o fetiche da imagem daí saído é muito poderoso. A imagem caricata do negro no programa de humor tem um efeito sobre o imaginário social que continua a perpetuar o negro estereotipado em tais imagens. São estereótipos raciais e sexuais que Spike Lee, trabalhando com os tipos (pois o tipo está muito próximo do estereótipo), discute nesse filme.

Queremos mostrar que Spike Lee faz essa discussão na contramão do convencional de Hollywood numa verdadeira crítica e desconstrução da imagem que podemos chamar de eurocêntrica (Shohat \& Stam, 2006). O cinema teve (e continua a ter) um peso muito grande na construção da representação social. $\mathrm{O}$ cinema, nascido na época dos grandes impérios e da luta pelo espaço vital (geográfico e social), muito mais do que um produto da indústria cultural, propaga uma visão de mundo no interior daquilo que os críticos culturais Shohat \& Stam (2006) definiram de imagem calcada no eurocentrismo - a imagem eurocêntrica. O eurocentrismo, mais do que uma ideologia do colonialismo e imperialismo no sentido vulgar desse conceito, é uma forma de pensar, um modelo de pensamento presente não só nos produtos culturais "ocidentais", como também na 
própria reflexão intelectual, epistemológica, religiosa e moral sobre tudo o que nos cerca. Para o eurocentrismo (Shohat \& Stam, 2006, p.19-35):

- A história segue uma trajetória que vai da Grécia clássica (construída como "pura", “ocidental" e “democrática”) à Roma imperial e, em seguida, às capitais metropolitanas da Europa e dos Estados Unidos. O eurocentrismo encara a história, portanto, como uma sequência de impérios: Pax Romana, Pax Hispanica, Pax Britannica, Pax Americana. De todo modo, a Europa é vista como o "motor" das mudanças históricas progressivas: lá inventaram a democracia, a sociedade de classes, o feudalismo, o capitalismo e a revolução industrial.

- O "Ocidente" progride naturalmente na direção das instituições democráticas (figuras como Torquemada, Mussolini e Hitler devem ser vistas como aberrações dentro dessa lógica de amnésia histórica e legitimação seletiva).

- As tradições democráticas não europeias são ignoradas; devem-se ocultar tanto as manipulações típicas da democracia formal do Ocidente quanto seu papel na subversão de democracias estrangeiras.

- As práticas opressivas do Ocidente são consideradas contingentes, acidentais e excepcionais. O colonialismo, o tráfico de escravos e o imperialismo jamais são vistos como resultados fundamentais dos abusos de poder do Ocidente.

- A produção cultural e material dos “outros” pode ser apropriada e suas conquistas negadas, enquanto o ato de apropriação que marca a antropofagia cultural europeia é glorificado. O Ocidente, como afirma Barbara Kirshenblatt-Gimblett, "rompe os laços entre as formas e suas origens, converte essas formas em influências, leva tais influências ao centro, deixa as origens nas margens e se parabeniza por ser tão cosmopolita”.

Quantas pessoas, por exemplo, já se perguntaram sobre as categorias que utilizamos para nos referirmos às regiões? Aquilo que o Ocidente chama de Oriente Médio, Oriente Próximo, por exemplo, os chineses denominam Ásia Menor. O “Ocidente", para os habitantes do Oriente Médio, não ia além das fronteiras do Norte da África (a região do Magreb). Mas que fique claro desde já: "dado que o eurocentrismo é um discurso historicamente situado e não uma herança genética, os europeus podem ser antieurocêntricos, assim como os não-europeus podem ser eurocêntricos" (ibidem, p.24-5). Enfim, não é preciso ter nascido na Europa para pensar de forma eurocêntricca, pois encontramos o eurocentrismo talvez muito mais forte em regiões não europeias, especialmente entre as elites dos países subdesenvolvidos; isso é importante para não essencializarmos o debate e os conceitos utilizados. Os filmes de aventura, de faroeste e de romance ambientados em paisagens rústicas habitados por povos "primitivos" foram importantes na construção, manutenção e perpetuação dessa forma de pensar e ver o mundo na medida em que o espectador se via como integrante da 
família colonizadora de terras selvagens, pois, se "do ponto de vista geográfico, o império se caracteriza pela descontinuidade, o cinema ajudou a consolidar um duplo sentimento de nacionalismo e imperialismo dentre inúmeros povos díspares que se sentiam, assim, membros de uma mesma comunidade" (ibidem, p.146). Ainda que as rivalidades nacionais existam, há a "grande comunidade" eurocêntrica e suas colônias "bem-sucedidas" como Estados Unidos, Canadá e Austrália. Acrescente-se a isso o fato de que, diferentemente da literatura, o cinema não exige das pessoas que o frequentam que elas sejam alfabetizadas, $o$ que alarga o seu público para a casa dos milhares, milhões e até mesmo bilhões - como a transmissão da entrega do Oscar, por exemplo, que só perde, em audiência, para a Copa do Mundo.

É essa visão de mundo que Spike Lee desconstrói sem resvalar para dogmatismos e para isso ele utiliza, não sabemos se de modo consciente ou apenas intuitivamente, dois grandes autores. Há em sua obra, e particularmente nesse filme, influências de dois importantes conceitos: o efeito de estranbamento de Bertold Brecht e a função social do riso formulado por Henri Bergson, by the way, europeus vivendo na Europa, mas com uma visão que ultrapassa o eurocentrismo tal como aqui definido e, ao contrário do que diz a crítica contemporânea, só reforça, salvo engano, a relativa atualidade de suas perspectivas (antiessencialistas) para a compreensão da cultura contemporânea. Vamos explorar esses dois conceitos nos tópicos que seguem, analisando algumas cenas e imagens do filme, sem, todavia, esgotar todos os seus significados.

\section{A função do riso}

O motivo do riso pode ser uma piada, um tombo, um filme de comédia, uma roupa engraçada etc. O senso comum, ao ver uma pessoa rir de um desses motivos, pensa que essa se encontra muito emocionada, tão emocionada que não se aguenta, que transborda de tanta emoção, e ri. Ao ver alguém rindo, pensamos que essa pessoa é até muito pacífica, despreocupada, e ri levando a vida sem grandes problemas. Mas essa visão é aquela que nos aparece de modo evidente e aquilo que se toma por evidente é apenas a naturalização de relações históricas que não aparecem como tais.

O riso, assim nos ensina Bergson (1993, p.19), tem como seu ambiente natural a indiferença. A insensibilidade acompanha o riso de mãos dadas. Ninguém jamais ri de uma pessoa que inspira piedade ou carinho, e mesmo quando assim age, a piedade e o carinho estão momentaneamente suspensos:

[...] uma sociedade de puras inteligências talvez já não chorasse, mas rir provavelmente ainda riria; ao passo que almas sempre igualmente sensíveis [...] não conheceriam nem compreenderiam o riso... O cômico exige, pois, finalmente, para produzir todo o seu efeito, qualquer coisa como uma anestesia momentânea do coração. Dirige-se à inteligência pura. (ibidem)

Mas que inteligência é essa a que o riso se dirige? É preciso falar em inteligências, no plural, pois o riso tem a necessidade do eco. E o eco a que se refere não 
é algo apenas metafórico. É o eco da sociedade, o meio natural do riso. Só se pode rir porque há outros que assim o fazem; ninguém ri sozinho de outra pessoa, pois, se assim o fizesse, estaria sendo imprudente. Isso é nítido no filme de Spike Lee. Quando as primeiras gravações do programa Mantan - o novo show do milênio são mostradas para o público, a câmera do diretor se volta para a plateia: qual é a reação do público? A câmera mostra, primeiro, o incômodo e um mal-estar de uma parcela do público com aquelas imagens, dois atores negros pintados de negros. Uma caricatura. Uma mulher branca olha discretamente para o lado, com a intenção de ver a reação de seu companheiro, um jovem negro. Esse, como a maioria dos negros, acha graça no que estão vendo. Os brancos da plateia, percebendo a reação de riso dos negros da plateia, se sentem autorizados e à vontade para rir também, afinal, eles próprios não estão rindo de si mesmos em nossa presença?

Mas o riso do negro na plateia que ri de si mesmo possui uma ambiguidade e, portanto, pode ser interpretado de duas maneiras, uma não aniquilando a outra. Primeiro, é próprio de qualquer grupo social - étnico, profissional, religioso etc. - rir de si mesmo enquanto estão reunidos. Aprendemos com Georg Simmel (1983) que o momento da sociabilidade é justamente o momento da suspensão das hierarquias nos espaços formais de nosso cotidiano. Não há uma profissão que não tenha um conjunto de anedotas sempre repetidas nas reuniões e/ou encontros anuais de suas associações. Assim é que uma piada de negro contada por um negro entre os negros não soa como racismo, mas como troça permitida no momento, e apenas no momento, da sociabilidade, e isso é válido para quaisquer outros grupos estigmatizados. Em $A$ hora do show, os negros da plateia riem porque são atores negros fazendo uma caricatura de si mesmos; se os atores fossem o outro, a ira se manifestaria na hora, e os brancos que riem nessa cena não aparecem aos negros ali presentes como o outro, pois foram levados pela massa que ri num momento de sociabilidade. Mas também o riso do negro que ri do negro interpretando o próprio negro tem algo de um auto-ódio próprio de grupos estigmatizados sobre os quais a sociologia e a psicanálise já se debruçaram muitas vezes. Rindo de si mesmo, o indivíduo estigmatizado grita: estou sujo, sou sujo... como a vítima de estupros que, após o ato, tenta limpar-se de tal sujeira. Já nem importa mais o que os outros pensam, afinal, já aconteceu... O negro que ri na plateia já nem se importa se o seu colega branco também ri, afinal...

O riso pressupõe cumplicidade com outros que riem, "reais ou imaginários", nos ensina Bergson (1993, p.20). Mas que ambiente permite a produção do riso? Não se trata de um ambiente mítico, imaginário ou psicológico, e quem procurar explicações dessa ordem está fadado ao fracasso. $\mathrm{O}$ ambiente do riso é concreto, muito mais concreto do que supõem algumas de suas abstratas interpretações: a sociedade. Essa é o seu meio natural. Ora, se a sociedade é o seu meio, logo, ele deve ter uma função na sociedade que o produz, quer dizer, o riso deve ter um significado social que devemos ir atrás. O riso nem sempre é consciente, aliás, pode-se mesmo dizer que ele, inconsciente para si, torna-se consciente, visível a toda a sociedade no momento em que é expresso. Mas 
quando ele é expresso? O cômico, diz Bergson (1993), parece surgir quando homens reunidos "em grupo dirigiram toda a sua atenção para um de entre eles, fazendo calar a sensibilidade e usando somente a inteligência".

A função do riso é reprimir toda e qualquer excentricidade. Isso porque o excêntrico é alguém que se isola, quer dizer, que não adota as convenções da sociedade e, por isso mesmo, a assusta, como o filho rebelde que, não obedecendo aos pais, amedronta-os com a possibilidade de impor novas regras no interior da casa. Assim,

[...] toda a rigidez de carácter, de espírito e até de corpo, será por isso suspeita à sociedade, porque ela é o sintoma possível duma actividade que adormece, duma actividade que se isola, que tende a fugir do centro comum em volta do qual a sociedade gravita, duma excentricidade, enfim. E, no entanto, neste caso, a sociedade não pode intervir por uma repressão material, visto não ter sido atingida materialmente. Encontra-se em presença de qualquer que a inquieta, mas apenas a título de sintoma, apenas uma ameaça, quando muito um gesto. E é por um simples gesto que ela responderá. O riso deve ser qualquer coisa neste género, uma espécie de gesto social. Pelo terror que inspira reprime as excentricidades, mantém constantemente despertas e em contacto recíproco certas atividades de ordem acessória que correriam o risco de se isolar e de se esbater, apaga, enfim, tudo que possa ficar de rigidez mecânica à superfície do corpo social. (Bergson, 1993, p.27-8)

$\mathrm{O}$ que faz rir, ou melhor, o que faz que a sociedade (a verdadeira protagonista do filme) ria do negro caricato em $A$ hora do show não é a suposta feiura concebida ao outro (entendendo por feio o padrão estético estabelecido pelo senso comum das sociedades), mas a rigidez e o mecanicismo com que a vida de um grupo social é representada.

O cômico tem sua natureza na rigidez e não na feiura, até mesmo porque essa é passível de contestação até mesmo no grupo dominante que estabelece o padrão estético (o senso comum estético do Ocidente, segundo a perspectiva de Ella Shohat e Robert Stam (2006), vem sendo contestado, especialmente, desde os anos 1960, não só pelos "condenados da terra" do mundo colonial, mas também por uma parcela da metrópole, como podemos notar no cinema de vanguarda). O cômico se opõe antes à graça do que à beleza; ele é a cristalização, o engessamento da alma:

As atitudes, gestos e movimentos do corpo humano são risíveis na medida exacta em que esse corpo nos faz pensar numa simples mecânica [...] É preciso que a cada instante mude, porque deixar de mudar seria deixar de viver. Como ele, o gesto deve, portanto, ser vivo; deve aceitar a lei fundamental da vida que é a de nunca se repetir. Mas eis que um certo movimento de braços ou de cabeça, o mesmo sempre, eu vejo repetir-se periodicamente. Se eu o noto, se é o suficiente para me distrair, se o espero num determinado momento e ele vem quando eu o espero, involuntariamente rio. Porquê? Porque tenho agora diante de mim uma mecânica que funciona automaticamente. Já não é vida: é o automatismo instalado na vida e imitando-a é o cômico. (ibidem, p.33-5) 


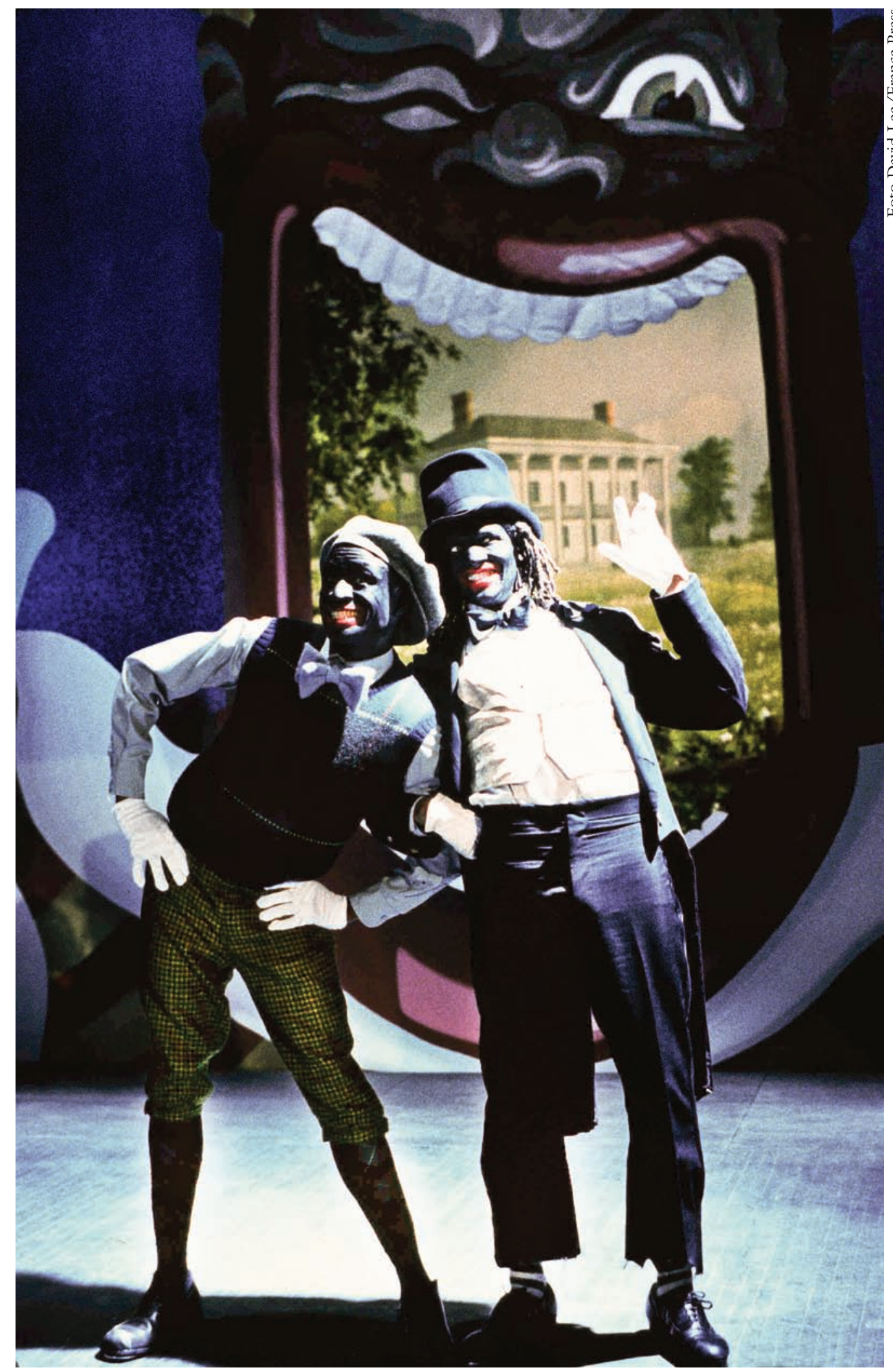

Personagens Tommy Davidson e Damon Wayans, do filme Bamboozled (2000), de Spike Lee. 
O automatismo do negro caricato que nos faz rir é a evidência do mecanicismo que tal pessoa (o negro) deixou introduzir em si próprio. Essa evidência, eis a nossa hipótese, é o trabalho repetitivo da escravidão moderna nas lavouras do continente americano que se perpetua no imaginário da sociedade. Ela foi extinta juridicamente ainda ontem, no século XIX (a nossa concepção de tempo é muito ampla), mas muito de suas representações foi refuncionalizado. Aquilo que antes era passível de piedade (o trabalho forçado e os castigos) hoje é passível de riso. Não é à toa que o programa apresentado pelo roteirista se passa justamente numa plantação de algodão típica da época colonial. Os personagens caricatos apresentados pelos atores são releituras dessa época: a mãe preta, o negro entertainment etc., não é por acaso que nos faz rir: são todos uma espécie de bonecos autômatos. E se a mecânica é a causa do riso, eis aí a causa do cômico de tais personagens. Duas fisionomias parecidas, dizia Pascal, "apesar de nenhuma delas fazer rir em separado, fazem rir juntas, pela sua parecença". Mas o riso "será bastante mais forte ainda se não nos apresentarem em cena apenas duas personagens, como no exemplo de Pascal, mas várias, o maior número possível, parecendo-se todas entre si, que vão, que vêm, dançam e se agitam ao mesmo tempo, tomando ao mesmo tempo as mesmas atitudes, gesticulando da mesma maneira" (ibidem, p.36).

É como se Bergson estivesse falando dos menestréis típicos da sociedade estadunidense do século XIX. Quanto mais personagens mecânicos, maior será o motivo e a vontade de rir. Aliás, o próprio Bergson, escrevendo o ensaio sobre o riso em 1899, toma justamente como exemplo o "preto" como (estereó)tipo, que estamos a tratar:

Porque rimos nós duma cabeleira que passou do preto ao loiro?... Porque rimos nós dum preto? Pergunta embaraçosa parece, visto que os psicólogos como Hecker, Kraepelin, Lipps a tentaram resolver e a responderam de maneiras diferentes. No entanto não sei se não teria sido resolvida um dia diante de mim, no meio da rua, por um simples cocheiro que tratava de "mal-lavado" um cliente negro sentado no seu carro. Mal-lavado! A cara dum preto seria assim, para a nossa imaginação, uma cara suja de tinta ou de fuligem. [...] Agora, mesmo sendo a coloração negra ou vermelha uma qualidade inerente à pele, tomamo-la por estampada artificialmente, porque nos surpreende. (ibidem, p.39-40)

A nossa imaginação de que fala Bergson é justamente a imaginação (e imagem) eurocêntrica.

Tais considerações são absurdos à razão (ao menos à razão que raciocina, naturalmente...), mas a razão cessa nas fronteiras da imaginação e da fantasia, já que essas possuem sua própria lógica. A imaginação e a fantasia de um indivíduo podem soar como loucura no interior da sociedade, mas que fazer quando tais imaginações são fantasiadas por toda a sociedade? Será toda a sociedade louca? O preconceito e o estigma retiram sua força dessa lógica do imaginário que não é a mesma da razão e que muitas vezes estão em oposição. Os personagens de 
Mantan - o show do milênio são apresentados como bonecos mecânicos que representam os sentimentos humanos, mas não são humanos, são seres mecânicos que agem como se fossem, mas não o são, apesar de conservarem o aspecto de verossimilhança. Daí talvez o seu sucesso... "É cômico todo o incidente que chama a nossa atenção para o físico duma pessoa quando é o moral que está em causa... Donde vem o cômico desta frase duma oração fúnebre, citada por um filósofo alemão: ‘Era virtuoso e gordo'?” (ibidem, p.45).

De onde vem o cômico de se ver atores negros representando caricaturalmente a si próprios? Na frase anterior de Bergson, temos uma qualidade de caráter, de sua alma - era virtuoso... - e uma descrição de seu fenótipo - e gordo! -; repare que na frase temos uma mudança brusca, um desvio de atenção no sentido estrito do termo dada a uma qualidade espiritual (virtuoso) para uma qualidade corporal (gordo). A inteligente observação de Bergson, isto é, do fato de a nossa atenção ser bruscamente desviada da alma para o corpo, pode ser generalizada para o filme de Spike Lee. Todo o filme se passa sempre de uma qualidade espiritual (positiva) para uma qualidade corporal (negativa). Não é à toa que Pierre Delacroix é a expressão máxima da qualidade espiritual (a imagem do negro bem-sucedido), o virtuoso, enquanto Mantan, sua criação, é a expressão corporal, o gordo da frase do filósofo alemão: os dois corpos dos excelentes atores negros expressando pela dança, sapateado, mímica, recitação, canções etc. tudo o que a sociedade ocidental (imagem eurocêntrica) sempre negou, a sensualidade do corpo: "Um indivíduo embaraçado pelo seu próprio corpo eis a imagem que nos é sugerida nestes exemplos" (ibidem, p.45-6). Para o eurocentrismo, é uma infâmia o corpo sobrepor-se à alma, como nos sugere esses exemplos, pois o corpo (negativo) importuna o espírito (positivo). E o Espírito, dizia um esteta nos inícios da modernidade, "não se emociona com o que Ele não acredita" (Boileau, s. d., p.27).

As representações em shows tais como menestréis, vaudevilles e correlatos, porém, só são possíveis porque permeiam o imaginário social, afinal nenhum indivíduo imagina sem referências de seu meio, e ainda que imagine algo totalmente novo, único e singular, teve que partir de algum ponto, qual seja, dos arquétipos e tipos que, como cartas de jogo, estão disponíveis à mão. $\mathrm{O}$ vandeville "é [para] a vida real o que o boneco articulado é para o homem que anda: um exagero assaz artificial duma certa rigidez natural das coisas. Bem frágil é o fio que o liga à vida real. Pouco mais é que um jogo subordinado, como todos os jogos, a uma convenção previamente aceite" (Bergson, 1993, p.77). Quanto mais o produtor cultural recria a realidade, mais mergulha nela para dela afastarse. A obra que menos cita a sociedade de seu tempo é a que mais a compreendeu. Isso não é um princípio tirado de algum manual de estética, apenas uma constatação histórica, pois a história demonstra que tem sido assim...

Bergson diz que o riso exprime uma inadaptação particular da pessoa à sociedade. Também podemos dizer que o riso exprime uma suposta inadaptação 
de determinados grupos sociais à sociedade, como mostra o filme de Spike Lee. Inadaptação deve ser tomada não como uma falta essencializada que legitima ainda mais os racismos, mas como intolerância de uma sociedade que não sabe conviver com a alteridade (Bauman, 1999), pois é bom que se distinga o discurso da aceitação do outro com o aspecto concreto de conviver com o outro. Posso muito bem aceitar o outro, mas não significa que irei conviver com ele; assim como posso conviver com o diferente sem necessariamente aceitá-lo; enfim, aceitar e conviver não são a mesma coisa. Pierre Delacroix é o exemplo do outro que trilhou o caminho que a sociedade recomenda, mas, quando assim o fez, essa mesma sociedade, por meio da rede de televisão em que trabalha e também do público, lhe diz que para ser (supostamente) aceito deve justamente "ser ele mesmo", isto é, produzir um programa sobre algo que ele conhece bem: o negro tratado geneticamente como um trickster, como alguém que serve apenas para divertir. É porque no fundo Delacroix nunca foi aceito, foi assim com o seu pai (o comediante Junebug), e a não aceitação é o princípio da comédia: "A comédia só começa naquele ponto em que a pessoa de outrem deixa de nos comover. E começa com o que se poderia chamar a rigidez contra a vida social" (Bergson, 1993, p.98).

O riso tem uma função social, humilhar o individuo ou o grupo que ameaça a sociedade e que tal ameaça seja real ou imaginária pouco importa: "Tal deve ser a função do riso. Sempre um pouco humilhante para quem é objecto dele, o riso é, verdadeiramente, uma espécie de assoada social" (ibidem, p.98). No cinema ou no teatro, o riso jamais vem de um prazer puro, desinteressado. Sempre traz algo de uma certa humilhação a que estão sujeitos determinados indivíduos ou grupos sociais. Como se dissesse a quem assiste ao filme ou a determinada peça - "isso acontece todo dia!". Mas o indivíduo humilhado nunca é o indivíduo anônimo; sempre um indivíduo adjetivado, encaixado numa determinada identidade social, num (estereó)tipo. Por exemplo, quando rimos de alguém que tomou um tombo, não estamos a rir menos do indivíduo chamado $\mathrm{X}$ e sim do indivíduo distraído, lerdo, bêbado, enfim tipos que já estavam na sociedade, pois "a comédia pinta caracteres que já encontramos e que encontraremos ainda no nosso caminho. Anota as semelhanças; procura apresentar-nos tipos e criará mesmo, quando disso tiver necessidade, tipos novos" (ibidem, p.106). O riso do telespectador no filme de Spike Lee soa como uma pena saída do código penal àqueles que, real ou imaginariamente, praticaram alguma transgressão:

Através dele [do riso] se vinga a sociedade das liberdades praticadas para com ela. Não atingiria o seu fim se trouxesse a marca da simpatia ou da bondade. [...] Grosso modo e duma maneira geral o riso exerce, sem dúvida, uma função útil. Todas as nossas análises tenderam, de resto, a demonstrá-lo. Mas não se segue daqui que o riso acerte sempre no alvo, nem que se inspire num pensamento de benevolência ou mesmo de equidade. (ibidem, p.103)

Durante todo o filme, o programa Mantan - o show do milênio não apresenta nenhuma ação, isto é, um desenvolvimento psicológico dos personagens. 
Os personagens simplesmente se mostram, expõem-se, apenas gesticulam, mais nada, não há histórias, apenas um esquema pronto - roupas, gestos, piadas etc. - a ser preenchido a cada programa. É que a ação não tem sentido na comédia, aliás, se tiver ação, não se tem comédia, pois nessa o que importa é apenas o gesto e mais nada, absolutamente mais nada. Os programas de humor demonstram isso muito bem, os personagens sempre têm os mesmos tiques, posturas, impostação de voz etc. O que interessa na comédia são apenas os gestos, como podemos assistir em $A$ hora do show, jamais a comoção advinda da ação (história de vida de um personagem), em resumo:

[...] vimos que um carácter pode ser bom ou mau, pouco importa; se for insociável poderá tornar-se cômico. Vemos agora que também não interessa a gravidade do caso: grave ou de pouca importância far-nos-á rir se as coisas se preparam para que não nos comovamos. Insociabilidade da personagem, insensibilidade do espectador, eis, em suma, as duas condições essenciais. (ibidem, p.104)

É sobre a relação entre espectador, ator e personagem que agora nos interessa porque é o momento em que a imagem eurocêntrica se institui (mas também pode ser destituída, desconstruída) como prática a surtir efeito (prático) na vida cotidiana, ou melhor, na luta cotidiana dos indivíduos e grupos para se tornarem senhores de sua própria representação contra as representações do outro de si próprios.

\section{$O$ efeito de estranhamento}

Falamos anteriormente que $A$ hora do show testa o diagnóstico feito por Bergson sobre o riso. Mas esse diagnóstico sobre o riso causado pelo negro como um arquétipo do trickster na indústria cultural não é novidade no cinema; muito ao contrário, é característico da imagem eurocêntrica pelo menos até os anos 1960. Ele aparece com o diretor americano D. W. Griffith em O nascimento de uma nação (1915), filme interpretado por atores brancos pintados de negro que retrata a guerra da Secessão, o assassinato de Abraham Lincoln e o nascimento da Ku Klux Klan (KKK). À época de seu lançamento, foi proibido em muitas cidades americanas (as grandes cidades, em sua maioria, como Los Angeles), em razão de seu conteúdo racista. Uma das curiosidades desse filme trata-se do fato de D. W. Griffith não ter escrito nenhum roteiro e não ter feito nenhuma anotação sobre como seriam as cenas filmadas. Aqui, queremos chamar a atenção menos para a (suposta) genialidade do artista do que para a força do imaginário social na genialidade do artista. A visão racista e estereotipada que pairava sobre o negro à época era tamanha que um diretor de cinema apologista da KKK não tinha necessidade de roteirizar o filme. Spike Lee faz a mesma coisa em seu filme, levando o diagnóstico aos extremos. Em seu filme, não aparecem brancos pintados de negro, mas atores negros pintados de negro. Esse fato causou certo incômodo na crítica cultural que parece não ter compreendido a sua intenção. A intenção do filme, essa é a nossa hipótese, é desnaturalizar o natural na imagem, e, para isso, o diretor faz uso do efeito de estranhamento - o efeito- 
V - criado por Bertold Brecht para um teatro épico com a intenção de superar o teatro burguês. $\mathrm{O}$ teatro épico de Brecht tem somente um único propósito: analisar a questão e só depois julgá-la. A “moral da história” não é a essência do teatro épico, como o é no teatro e na fábula burgueses. Nesses, como mostrou Brecht (1978b, p.63) em um importante ensaio intitulado "Efeitos de distanciamento na arte dramática chinesa", o ambiente está sempre subordinado ao personagem:

[...] o que o teatro burguês sempre realça nos seus temas é a intemporalidade que os caracteriza. Apresenta-nos uma descrição do homem subordinada por completo ao conceito do chamado "eterno humano". Estrutura a fábula de modo que o homem de todas as épocas e de todas as cores - o homem, pura e simplesmente - possa ser expresso através dela... Num tópico pode ter-se em conta tudo o que é especial e diverso; a resposta, porém, é geral, na resposta não há diversidade alguma... modificam-se algumas das circunstâncias, transformam-se os ambientes, mas o homem não se modifica. A história é uma realidade no que se refere ao ambiente, mas não o é em relação ao homem.

Em $A$ hora do show, a história é uma realidade não somente em relação ao ambiente, mas também em relação aos homens e às mulheres ali presentes. Spike Lee, como se seguisse um conselho de Brecht, dá realce ao ambiente em que mulheres e homens vivem para se ter uma exata compreensão de por que mulheres e homens vivem assim e não de outra forma. Em todo o filme, não há a história de um indivíduo, de um herói, que se defronta com determinadas circunstâncias e que as vai resolvendo pouco a pouco ao longo da caminhada. Pierre Delacroix é só o ponto de partida para a análise de todo um complexo de relações históricas que perpassa a noção social de raça, de gênero e de estratificações sociais. Pierre Delacroix não é apenas o personagem de um ator (Damon Wayans) que o interpreta, ele é uma perspectiva da narrativa, um narrador que cita o desenrolar dos acontecimentos e que num determinado momento se vê no meio de tais acontecimentos, quando propõe o programa e depois tem de assumir as responsabilidades perante a comunidade insatisfeita, por causa do seu conteúdo preconceituoso.

Quando Spike Lee, em vez de colocar atores brancos pintados de negro para fazer o programa, coloca atores negros pintados de negro, temos aí uma crítica ao evidente. Se fossem atores brancos pintados, teríamos um julgamento moral: os brancos não podem desrespeitar os neguinhos! A discussão continuaria: tribunal, liberdade, intolerância etc., enfim, os mesmos argumentos tornados como eternos e não como mutáveis ao longo da história. Quando são atores negros pintados de negros, a discussão ganha um caráter sensacional, e não é sem razão que a palavra sensacional tem uma conotação pejorativa na sociedade burguesa, basta ver como o termo sensacionalismo aparece no cotidiano dos meios de comunicação de massa e é abraçado por intelectuais. Acusa-se sempre o adversário de... Sensacionalista! Os negros pintados de negro permitem uma discussão, uma análise da situação, aqui a do racismo, tanto pelos racistas 
para que vejam que suas práticas e ideias são racistas quanto pelos que sofrem o racismo para que tomem uma posição quanto ao racismo. Compreender uma situação é fazer uma crítica do evidente: "Em tudo o que é evidente, é hábito renunciar-se, muito simplesmente, ao ato de compreender. O que era natural tinha, pois, de adquirir um caráter sensacional. Só assim as leis de causa e de efeito podiam ser postas em relevo" (Brecht, 1978a, p.47).

Spike Lee, ao colocar atores negros pintados de negro, está fazendo uso daquilo que Brecht (1978b, p.56) chamou de efeitos de distanciamento, algo muito comum na arte dramática chinesa:

$\mathrm{O}$ artista chinês não representa como se além das três paredes que o rodeiam existisse, ainda, uma quarta. Manifesta saber que estão assistindo ao que faz. Tal circunstância afasta, desde logo, a possibilidade de vir a produzir-se um determinado gênero de ilusão característico dos palcos europeus. O público já não pode ter, assim, a ilusão de ser o espectador impressentido de um acontecimento em curso. [...] Outra medida técnica: o artista é um espectador de si próprio. Ao representar, por exemplo, uma nuvem [...] olha, por vezes, para o espectador, como se quisesse dizer-lhe: "Não é assim mesmo?”.

Mantan, o sapateador, diz para quem o vê: não é assim mesmo que vocês nos veem? Todavia, ele não se dirige diretamente para a plateia do cinema, mas para uma plateia da plateia. Isso permite o distanciamento, que faz que o espectador tenha sua própria opinião sobre o filme e o personagem, ultrapassando a evidência. Spike Lee faz-nos pensar em racismo sem essencializar a raça, isto é, tomando a raça (uma construção social) como algo natural. Mais do que desnaturalizar o social, o diretor desnaturaliza o natural - a ideia de raça - e traz o telespectador para participar nesse processo. A hora do show não toma partido, é mera exposição de como aquela situação chegou a ser o que é. Nas últimas cenas do filme, Mantan, após ter se revoltado com o diretor da rede de televisão e se rebelado ao vivo no programa, demite-se e vai embora. Mas é tarde, porque os Mau-Mau, grupo de rapper radical que exige a "libertação total do povo negro", o espera. Ele é sequestrado pelo grupo, esse avisa a toda a imprensa que irá matá-lo ao vivo na TV. Quando o dia chega, é incrível como o diretor nos faz pensar em todo o complexo histórico que levou àquela situação. O telespectador toma partido - deixe Mantan viver, ele se rebelou! -, outro telespectador também toma partido - mas o grupo não está errado, eles nem sabem que Mantan se rebelou!... Isso só é possível por causa do distanciamento que Spike Lee tenciona, não sabemos se de modo consciente, entre atores e personagens.

O ator ocidental, formado na visão de mundo eurocêntrica, tem como objetivo aproximar ator e personagem num só, fundindo todas as suas emoções, aproximando o espectador dos sentimentos do personagem. Quem assiste a telenovelas brasileiras e filmes holliwoodianos sabe que os "bons atores" são julgados por esse critério: “Como interpreta bem! Nem parece que está representando!", diz o senso comum tanto da crítica quanto do público sobre uma boa atriz 
e um bom ator... Mas essa técnica é muito extenuante, e, no teatro, poucos são os atores que conseguem manter a mesma energia ao longo dos espetáculos:

[...] para o ator é difícil e cansativo provocar em si, todas as noites, determinadas emoções ou estados de alma; em contrapartida, é-lhe mais fácil revelar os indícios externos que acompanham e denunciam essas emoções. Mas a transmissão de emoções ao espectador - contágio emocional - não é, decerto, uma transmissão pura e simples. (ibidem, p.60)

Nós estamos falando de cinema, é verdade, mas essa técnica de fundir ator e personagem talvez se revele ainda mais eficaz na medida em que, terminado o filme, ator e personagem estejam cristalizados na película. Esse ator, diz Brecht, ao metamorfosear-se em algum balconista, meretriz ou general necessita de tão pouca arte como a que o balconista, a meretriz ou o general necessitam na vida cotidiana. E o seu efeito não é aquele da sensualidade da obra de arte: "O ator ocidental produziria efeito idêntico ao de um ilusionista de feira que deixa todos os truques à vista, o que faz com que ninguém esteja disposto a ver segunda vez a mesma cena [ou o mesmo filme]; apenas mostraria como é que se finge” (ibidem, p.59). Raramente assistimos ao mesmo filme por fruição estética. Já sabemos o truque. O efeito de distanciamento soa a alguns como algo frio e chato, o que não é verdade, pois Brecht mesmo dizia que o teatro é uma forma de aprender divertindo. É o caráter de exposição do efeito de distanciamento que incomoda o telespectador e o crítico que naturalizaram a interpretação via fundição ator e personagem. Com o efeito de estranhamento o cotidiano ultrapassa a evidência (ibidem, p.57), daí talvez a sua "frieza" quando "sentimos" a distância entre ator e personagem:

[...] esta aparente frieza de sentimentos é conseqüência do referido distanciamento do ator em relação à personagem que apresenta. Evita, assim, que as sensações das personagens se tornem sensações do espectador. $\mathrm{O}$ indivíduo que o ator representa não exerce qualquer violência sobre ninguém, não é o próprio espectador; é, antes, um seu vizinho. (ibidem, p.58)

No filme $A$ hora do show, o distanciamento não se apresenta despido de emoções, pelo contrário, são mostradas determinadas emoções que não necessitam ser encobertas pelos personagens. A discussão entre Man Ray (Savion Glover) e Come-e-Dorme (Tommy Davidson), os dois atores protagonistas de Mantan, quando esse resolve não mais se submeter ao papel humilhante, ao papel de ser objeto do riso do outro, mostra o ator não como personagem, mas o ator expondo os sentimentos do personagem sem se fundir com ele. E é uma cena que emociona e que analisa porque traz o ambiente para as relações entre os homens, é o ator refletindo sobre o ambiente e não o ambiente como apêndice das peripécias do herói, e aqui há ecos de Brecht em Spike Lee. Esse efeito sobre o telespectador é bem diferente daquele estabelecido por Stanislavski. ${ }^{1} \mathrm{O}$ ator chinês, dizia Brecht (1978b, p.62), testemunha a magia: "é do testemunho da magia que o artista chinês extrai o seu efeito de distanciamento". Ele diz como funciona e nesse sentido ele jamais violenta o espectador, pois esse sabe 
que está sendo submetido à magia não antes ou depois, mas durante o espetáculo. A hora do show testemunha desde o início como se produz o efeito mágico de um corpo (negro) cercado pela sociedade (branca).

Os acontecimentos em $A$ hora do show não são mais evidentes porque exigem uma explicação. Para ser mais claro, quem assistir a qualquer outro filme que envolva a cultura afro-americana (americana no sentido geográfico: brasileira, estadunidense, caribenha) notará como os negros aparecem demasiadamente estetizados, uma das modalidades da exotização. Num filme como $\mathrm{Be}$ Cool -o outro nome do jogo, por exemplo (aliás, um bom filme), mas poderia ser qualquer outro (como os filmes do diretor brasileiro Cacá Diegues), os negros aparecem como se dissessem "Cheguei!", raramente como um personagem que partilha da trama da história sob o âmbito da normalidade (do que a sociedade entende por isso, naturalmente): o seu corpo, a sua roupa, a sua fala, a sua dança, em suma, o seu estilo é destacado de uma forma tal que a intenção primeira do politicamente correto - respeitar a diferença - é desviada - nossa que coisa diferente! - e a lógica da dominação continua a perpetuar-se. Sob tal perspectiva não há uma diferença psíquica e socialmente objetiva (e daí a relevância das confluências das perspectivas psicanalítica e sociológica) entre o "racista" e o "exótico", pelo menos para o agente (o outro "dominado") no momento do conflito, pois, como demonstrou Phyllis Rose:

[...] o exotismo utiliza seu objeto para o prazer do dominador, tomando o “outro" colonizado como uma ficção erótica que mistifica o mundo [...] enquanto os racistas são ameaçados pela diferença, os amantes do exótico a acham divertida [...]. O racista é como um garoto pobre que cresceu precisando de alguém para machucar. $\mathrm{O}$ amante do exótico cresceu rico e um pouco entediado. O racista se vê cercado de perigos, o amante do exótico se vê rodeado por brinquedos usados. (apud Shohat \& Stam, 2006, p.49)

$A$ hora do show não apenas faz uso da estética, ele é uma reflexão sobre as suas mazelas e grandezas: o que é mais estético do que Mantan - o show do milênio? - mas raramente temos a sensação de estarmos fruindo esteticamente essa película. É que aqui vamos tomando consciência histórica de como a estetização veio se erigindo da barbárie, isto é, do papel humilhante a que artistas tiveram que se submeter ao longo da história do show business americano: os menestréis talvez sejam a sua pré-história. A parte final do filme aliada a uma bela trilha sonora, no qual o diretor perpassa como o negro foi historicamente construído (os durkheimianos diriam socialmente representados) pela imagem eurocêntrica no cinema, nos desenhos e seriados, curiosamente, é onde mais temos a sensação de fruir esteticamente a imagem à nossa frente, mas uma fruição distanciada, porque não conseguimos nos colocar no lugar deles. Não apenas o espectador do teatro dramático do tempo de Brecht (1978a, p.48), também o telespectador de telenovelas e o público dos filmes de Hollywood dizem: "Sim, eu também já senti isso. - Eu sou assim. - O sofrimento deste homem comove-me, pois é irremediável. É uma coisa natural. - Será sempre assim. - Isto é que é arte! Tudo 
ali é evidente. - Choro com os que choram e rio com os que riem". Não é essa a reação evidente do (tele)espectador que se encontra diante de $A$ hora do show, mas aquele outro pretendido pelo teatro épico que diz: “- Isso é que eu nunca pensaria. - Não é assim que se deve fazer. - Que coisa extraordinária, quase inacreditável. - Isto tem que acabar. - $\mathrm{O}$ sofrimento deste homem comove-me porque seria remediável. - Isto é que é arte! Nada ali é evidente. - Rio de quem chora e choro com os que riem" (ibidem, p.48). O (tele)espectador não julga de antemão, vai analisando e tomando posições quanto ao desenrolar dos acontecimentos.

\section{Conclusão didática}

De tudo o que foi argumentado até aqui, é preciso deixar claro: o fato de utilizarmos o conceito de riso de Bergson ou de encontrarmos elementos brechtianos em $A$ hora do show não significa afirmar que o principal realizador dessa película tenha adotado a perspectiva filosófica de Bergson e/ou que seja brechtiano (e muito menos marxista). A proposta do artigo (e talvez daí a sua relevância) é mostrar como tais autores, se atualizados e trabalhados com maturidade, são de grande valia para uma reflexão sobre a produção cultural atual. Sobre os argumentos de Bergson sobre a função social do riso, por exemplo, temos a impressão de que ele está a analisar os programas humorísticos de TV: parecem ter sido escritos hoje! - Visto de uma perspectiva histórica, anteciparam muito das discussões e temas atualmente importantes - em especial, o tema da alteridade - que o eurocentrismo não hesita em explicar, mas com dificuldades de aceitá-la e compreendê-la.

Não há em Spike Lee nenhuma tomada de posição política como Brecht o fez em seu trabalho e obra. Isso é importante para que se evite tomar a proposta de determinado autor e sair por aí utilizando-a para a explicação de qualquer coisa. Estamos cientes de que Bertold Brecht tinha um projeto em que não separava estética e política, contexto histórico e biografias individuais. Nesse ponto pode ter sido contraditório, e como dialético que era, aceitava a contradição, mas jamais foi incoerente e nisso até mesmo os seus críticos e/ou inimigos mais severos reconheceram a sua integridade intelectual. Fredric Jameson (1999), o mais refinado dos marxistas contemporâneos, argumentou que a proposta de Brecht foi ordenada mais em forma de método de criação estética e intervenção política no ambiente histórico de seu tempo do que meras compilações ou pressupostos. A questão do didatismo em arte de que tanto se ocupou Brecht, por exemplo, é uma questão moderna, isto é, da arte moderna:

[...] o tabu que recai sobre o didático em arte (que nós, "ocidentais" modernos, pressupomos) é de fato em si próprio um traço de nossa própria modernidade. Nenhuma das grandes civilizações pré-capitalistas clássicas jamais duvidou de que sua arte tivesse alguma vocação didática fundamental; recuperar aquela vocação é muito precisamente o sentido daquilo que poderia ser chamado de a dimensão chinesa de Brecht... (Jameson, 1999, p.16) 
Ao contrário do que afirma a crítica avessa a tal discussão, uma obra de arte didática não pressupõe uma obra já "mastigada" para o público que a irá consumir, pelo contrário, as obras modernas exigem um leitor/espectador extremamente ativo, quer dizer, que brigue, que questione, que interprete, que discorde da obra (moderna) com que se defronta, e é esse traço característico que faz que a obra não vire peça de antiquário, na qual todos a respeitam pela sua suposta raridade, sem jamais interrogá-la justamente por sua raridade. Não é ao léu que o dramaturgo alemão definia o seu teatro épico como antiaristotélico: o que é antigo está mais próximo do natural, dizia Aristóteles (2000), e é essa naturalização da história e das relações entre os homens que Brecht tem a intenção de desnaturalizar, trazendo para o âmbito da estética o pensamento histórico. Ele não se baseia na empatia, tão cara a Aristóteles, pois, em sua obra, há uma preocupação pedagógica: "em Brecht como em Platão é o aspecto pedagógico sobredeterminante que justifica as posições aparentemente antiestéticas" (Jameson, 1999, p.65). Isso é válido para entender a trama de $A$ hora do show. As posições antiestéticas são aparentes porque algumas técnicas utilizadas no filme - o cenário, o uso da música, o recorte de cenas de outros filmes e desenhos em que o negro aparece como tipo - possuem um simbolismo sui generis que ultrapassa os seus significados evidentes, pois, ao contrário de um filme como $\mathrm{Be}$ Cool, por exemplo, em que tais técnicas aparecem como um fim em si mesmas (estetização em si mesma melhor seria), em $A$ hora do show elas são meios para atingir um fim: uma obra estética didática e, portanto, pedagógica, em vez de uma obra de entretenimento (que não deve ser confundida com diversão). Nesse ponto, e somente nesse talvez, encontramos alguns elementos brechtianos em Spike Lee.

A hora do show é uma obra épica. A noção de épico, é bom frisar, como o fez Jameson em seu arguto ensaio, não deve ser tomada na acepção corrente do cânone literário ocidental, isto é, associada às formas clássicas da tradição homérica e da exaltação do herói, mas como monotonia, rotina, cotidiano narrado pelo ato de contar histórias, apenas isso. Em Brecht (1978d), o teatro épico é um teatro-narrativa que se opõe às peças do drama burguês com moral da história. É "um teatro que narra histórias versus peças de oratória, um fato conduzindo ao outro em lugar de posturas e poses em conflito escultural" (Jameson, 1999, p.70). A hora do show retoma essa noção quase esquecida (ou ignorada?) do épico. Em uma cena, Pierre Delacroix, convidado por uma emissora de rádio a falar sobre o novo programa televisivo, ao ser indagado pelo radialista sobre a escravidão, diz, desdenhoso e distante da história: "A escravidão foi há quatrocentos anos!”. O radialista, estupefato, faz o homem culto de Harvard relembrar algumas datas: "A escravidão não foi há 400 anos, ela acabou [nos Estados Unidos] há apenas 135 anos; sabia que o seu bisavô foi um escravo?”. Em $A$ hora do show, o grande show da vida de um povo emergido da escravidão não aparece de forma estetizada como em muitos livros e filmes etnográficos, 
científicos na aparência - no plano da evidência para utilizarmos o vocabulário brechtiano -, mas traz em sua essência a marca repressiva das análises conservadoras. Os personagens também não aparecem como meras vítimas, o próprio Delacroix é a encarnação da ambivalência, isto é, do oprimido que, violentado pelo opressor, aprendeu a violentar outros oprimidos, tornando-se também um opressor. Enfim, por meio do uso épico e didático do efeito de distanciamento, compreendemos que o negro entertainer como arquétipo do trickster, até então considerado como eterno, lógico e natural, mostrou-se um produto histórico das relações entre mulheres e homens:

[...] o ato reificado, com seu nome e conceito - [revelou-se] como simplesmente histórico, como um tipo de instituição que passou a existir devido às ações históricas e coletivas do povo e de suas sociedades, e que, portanto, se revela como passível de mudança. O que a história solidificou sob a forma de estabilidade e substancialidade pode agora ser dissolvido novamente... (Jameson, 1999, p.75)

Nesse aspecto, Spike Lee, como Bergson e como Brecht, não julgou, apenas analisou a complexa situação que se propôs epicamente a narrar.

Nota

I Stanislavski - faça-se justiça quando do debate sobre o ofício do ator - é muitas vezes assaz incompreendido quando contraposto de forma maniqueísta à estética de Brecht. Talvez agora, com um relativo distanciamento histórico, podemos ver com nitidez como foi a recepção de sua proposta, por exemplo, nos Estados Unidos. Sobre isso, ver o artigo de Costa (2002).

Referências

Filmes

A hora do show. (Bamboozled). Direção: Spike Lee. Roteiro: Spike Lee. Fotografia: Ellen Kuras. Montagem: Sam Pollard. Elenco: Damon Wayans, Savion Glover, Jada PinkettSmith, Tommy Davidson e Michael Rapaport. EUA, 2000. Drama, 135 minutos. Distribuição: Playarte.

Be Cool - o outro nome do jogo. Direção: F. Gary Gray. Roteiro: Peter Seinfeld, baseado em livro de Elmore Leonard. Fotografia: Jeffrey L. Kimball. Montagem: Sheldon Kahn. Elenco: John Travolta, Uma Thurman, Vince Vaughn, Harvey Keitel, Dwayne “The Rock" Johnson, Danny DeVito, James Woods, Christina Milian. EUA, 2000. Comédia, 2005 - 114 minutos. Distribuição: MGM Distributing Corporation / 20th Century Fox.

\section{Obras}

ARISTÓTELES. Retórica das paixões. Trad. Isis B.B. Fonseca. São Paulo: Martins Fontes, 2000. 
BAUMAN, Z. Modernidade e ambivalência. Trad. Marcus Penchel. Rio de Janeiro: Jorge Zahar, 1999.

BERGSON, H. O riso. Ensaio sobre o significado do cômico. Trad. Guilherme de Castilho. 2.ed. Lisboa: Guimarães Editores, 1993.

BOILEAU, N. Art poetique. Paris: J. Claye, s. d.

BRECHT, B. Teatro recreativo e teatro didático. In: Estudos sobre teatro. Trad. Fiama Pais Brandão. Rio de Janeiro: Nova Fronteira, 1978a. p.45-54.

Efeitos de distanciamento na arte dramática chinesa. In: Estudos sobre teatro. Trad. Fiama Pais Brandão. Rio de Janeiro: Nova Fronteira, 1978b. p.55-66. As cenas de rua. In: Estudos sobre teatro. Trad. Fiama Pais Brandão. Rio de Janeiro: Nova Fronteira, 1978c. p.67-78.

. A nova técnica da arte de representar. In: . Estudos sobre teatro. Trad. Fiama Pais Brandão. Rio de Janeiro: Nova Fronteira, 1978d. p.79-86.

COSTA, I. C. Stanislavski na cena americana. Estudos Avançados, São Paulo, n.46, p.105-12, dez. 2002.

JAMESON, F. O método Brecht. Trad. Maria S. Betti. Petrópolis: Vozes, 1999.

JUNG, C. G. Os arquétipos e o inconsciente coletivo. Trad. M. L. Appy, Dora M. R. F. Silva. Petrópolis: Vozes, 2000.

ROSE, P. Cleopatra do Jazz: Josephine Baker e seu tempo. Trad. Waldéa Barcellos. Rio de Janeiro: Rocco, 1990.

SAID, E. Narrative and geography. New Left Review, n.180, p.81-100, Mar./Apr. 1990.

SHOHAT, E.; STAM, R. Critica da imagem eurocêntrica. Trad. Marcos Soares. São Paulo: Cosac Naify, 2006.

SIMMEL, G. Sociabilidade - um exemplo de sociologia pura ou formal. In: MORAES, E. (Org.) Sociologia: Simmel. São Paulo: Ática, 1983. p.165-81.

RESUMO - O artigo é uma análise crítica do filme $A$ hora do show (Bamboozled), lançado em 2000, do diretor estadunidense Spike Lee. Há em sua obra, e particularmente nesse filme, influências conceituais de dois importantes autores. De Bertold Brecht e o seu efeito de estranhamento ou efeito $V$ (do alemão Verfremdungseffekt); e de Henri Bergson e sua concepção do riso como portador de determinada função e significado social. A obra de Spike Lee, aberta no sentido modernista, perpassa uma intenção didáticopedagógica do uso e da desconstrução da imagem eurocêntrica que ainda não foi suficientemente analisada e compreendida pela crítica.

PALAVRAS-CHAVE: Imagem, Pedagogia, Efeito de estranhamento (efeito V), Riso, Eurocentrismo. 
ABSTRACT - This article is a critical analysis from Bamboozled film, launched in 2000 by Spike Lee. In his work, particularly in this film, there are conceptual influences from two of the most important authors: Bertold Brecht and his alienation effect or " $V$-effekt" (from the German Verfremdungseffekt), and Henri Bergson with his conception of laughter and its specific function and social meaning. The Spike Lee's work, opened in the modernist sense, brings a didactic-pedagogic intention about the using and the deconstruction of Eurocentric image - which has not been sufficiently examined and understood by the criticism yet.

KErWORDS: Image, Pedagogy, Alienation effect ( $V$-effekt), Laughter, Eurocentrism.

Pablo Augusto Silva é mestre em Sociologia pela Unicamp, docente na UAB-UFSCar (www.uab.ufscar.br). @-pablo.gutto@gmail.com

Rogério Ferreira Antunes é bacharel em Pedagogia pela Unicamp, pesquisador integrante do Olho - Laboratório de Estudos Audiovisuais da Faculdade de Educação/ Unicamp e Lattes - Diretório dos Grupos de Pesquisa no Brasil.

$@$ - rogerfas@yahoo.com.br

Recebido em 15.1.2008 e aceito em 26.9.2008. 